\title{
The discovery and early study of acidification of lakes in Sweden
}

\author{
This article belongs to Ambio's 50th Anniversary Collection. Theme: Acidification
}

\author{
Brodde Almer, William Dickson
}

Published online: 8 December 2020

The Swedish Environmental Protection Agency was created in 1967 and at the top of its agenda was acidification. At that time, Sweden emitted more sulfur dioxide than ever before, one million tons per year. In addition, prevailing westerly wind systems brought sulfur dioxide from the industries of North-western Europe to Scandinavia. William Dickson worked at the Environmental Protection Agency's Survey Laboratory located in Drottningholm outside Stockholm. Water samples were sent to him from committed officials at the county administrative boards and regional fishery boards in southern Sweden. They were concerned about the impaired quality of water for consumption and for fish. Dickson remembers that some lake water samples from "pristine" forest lakes even smelled like a petrol station and had a $\mathrm{pH}$ below 4 .

In the beginning of 1964, fisheries consultant Ulf Lundin measured a $\mathrm{pH}$ as low as 3.7 in the clear-water Lake Tolsjön outside Gothenburg. There were no signs of pollution in the catchment area of the lake. This was the first documented case of acidification affecting fish in Sweden (Fig. 1). From the southern parts of Norway came reports in 1968 and onwards about how acid rain badly affected rivers with salmon (Salmo salar) and lakes with trout (Salmo trutta) and char (Salvelinus alpinus). Also from the Adirondack Mountains in northeastern USA came reports of severe effects on fish caused by acid rain.

Brodde Almer, Institute of Freshwater Research, Drottningholm investigated in the summer of 1970, 105 brooks and rivers draining towards the Skagerrak Sea were investigated from around Gothenburg up to the border of Norway. Trout had in some waters decreased or in upper parts of streams become exterminated due to the acidification. In the autumn of 1970, pH was measured in 314 lakes at the West Coast of Sweden, many of them were severely influenced by acidification. In a subset of 50 lakes with $\mathrm{pH}$ ranging from 4.40 to 7.45 , a fish survey, including interviews, was performed in the summer of 1971 (Almer 1972). In the poorly buffered forest lakes, the decrease in $\mathrm{pH}$ was clearly harmful. In clear-water lakes, fish fauna was subject to considerable and, in certain cases, drastic changes. It became obvious that the fish stocks would be exterminated in the most acidified lakes if they were not limed.

The roach (Leuciscus rutilus) proved to be a good first indicator of lake acidification since the disturbances in the reproduction that were evident at $\mathrm{pH}<5.5$. During a survey in 1976, it was noted that, if the lakes had not been limed during the period from 1925 to 1974,18 out of 48 stocks of roach would have been eradicated due to acidification. Perch (Perca fluviatilis) and pike (Esox lucius) were not as sensitive as the roach but still negatively affected when $\mathrm{pH}$ fell under 5. Fish in the brown-water (humic) lakes were less sensitive than those in clear-water lakes.

The first report from the large study of 314 lakes was written in Swedish (Almer 1972) and submitted in March 1971 to the UN's first Environmental Conference, which was held in Stockholm in the summer of 1972. Erik Arrhenius, Science Editor of Ambio-A Journal of the Human Environment, heard about the report and encouraged us to submit our results in the newly started journal (Almer et al. 1974). Once published, the response to our report was not long in coming. Reactions came from the chemical industry and from the oil and coal producers, from forest and water researchers, but also from officials of the Swedish Environmental Protection Agency and the Swedish Board of Fisheries. We were invited to universities, meetings with the government and municipal health events.

Representatives of industry initially questioned the existence of acidification. Once they accepted that it was apparent at least in poorly buffered lakes, the usual reaction 


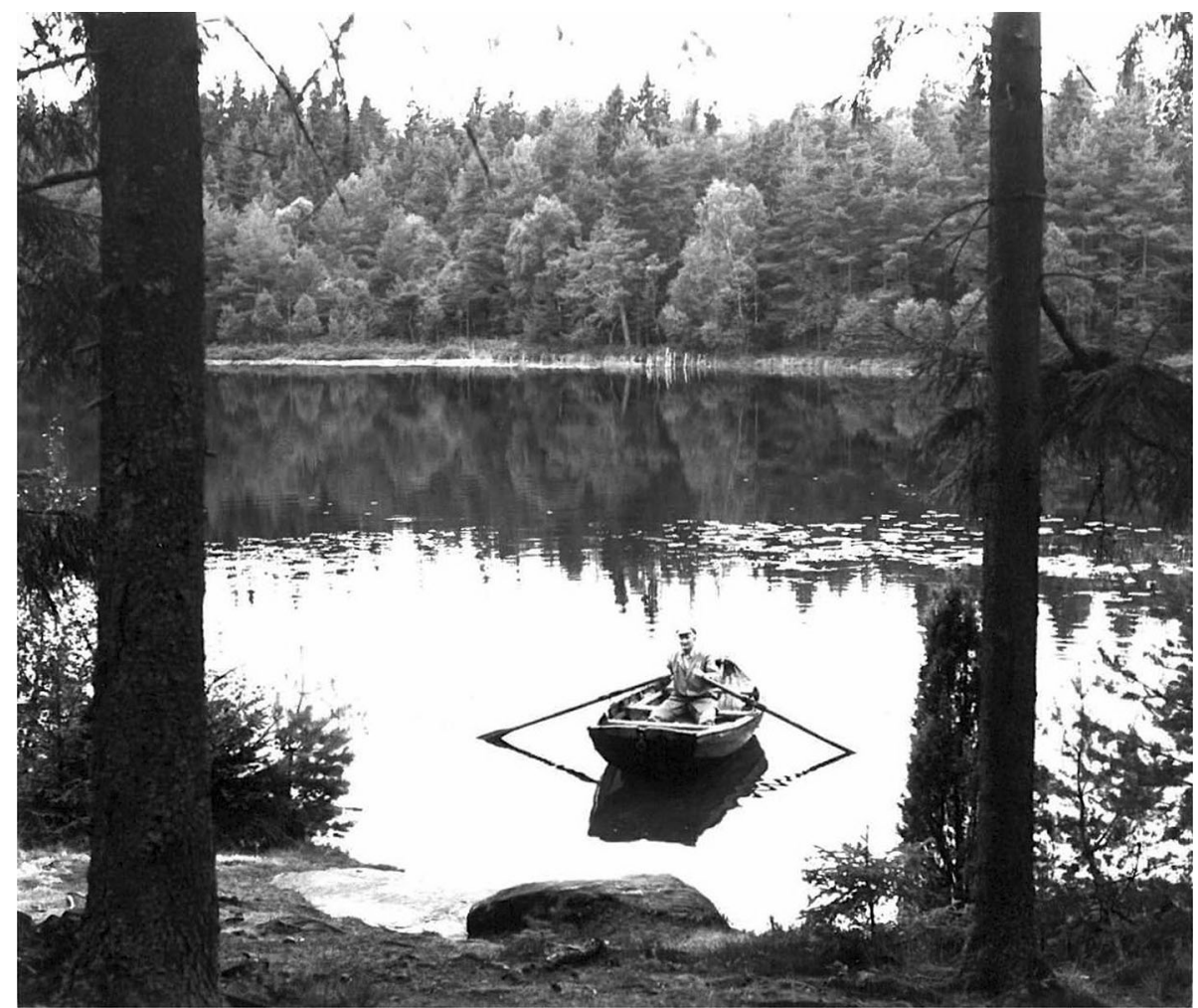

Fig. 1 Erik Andreasson started angling in Lake Tolsjön $\left(57^{\circ} 42^{\prime} 1.5^{\prime \prime} \mathrm{N}, 12^{\circ} 15^{\prime} 21.4^{\prime \prime}\right.$ E, east of Gothenburg, Sweden) around 1910 when roach (Leuciscus rutilus) were big and few-no reproduction. Only 5 years later, they had disappeared completely. The last pike (Exox lucius) caught around 1930. At that time nearly all perch (Perca fluviatilis) individuals were small. In the 1950s, perch individuals were much fewer but bigger suggesting hampered reproduction; the last ones were caught around 1960 and had a weight of $0.5 \mathrm{~kg}$. By then, the $2.2 \mathrm{ha}$ and $9 \mathrm{~m}$ deep Lake Tolsjön was void of fish! Intervju and photo 1983 by Brodde Almer

was: "So, why don't you lime them?". The English and Swedish coal and oil producers were willing to fund all liming activities in close connection to their power plants and also fund liming further away when there were valuable fish spawning waters. Compared to reduction of sulfur emissions, everything else was cheaper. In Sweden, however, we considered "we can do liming ourselves." Using government funds including support to the unemployed, we started liming valuable lakes as early as 1970 . The Swedish Environmental Protection Agency's Research Laboratory participated with advice and action, and it went well.

In the autumn of 1973, Torsten B. Hasselrot entered William Dicksons' office at Drottningholm. In his research, Torsten used fish as a biological parameter of water-polluting emissions. He studied the effects on fish of iron salts, added to wastewater to precipitate phosphate. Experiments included treatments with iron chloride, and controls where aluminum salts were added. He was concerned: "The fish died in the aluminum basins." Very interesting! The aluminum concentrations used in the experiment were similar to those found in the acidified char lakes, which we had begun to investigate. We found corroborating evidence in an article from 1939, which showed how sensitive fish (in

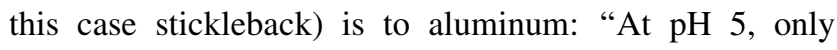
$100 \mu \mathrm{g} / \mathrm{l}$ is enough to kill sensitive species" (Erichsen Jones 1939).

In December 1973, we submitted the last changes in the proofreading of our report to Ambio and asked for space for an additional picture demonstrating the coupling of $\mathrm{pH}$ and aluminum. Our request was rejected-the Ambio editors were probably impatient to get the story into print-and the $\mathrm{pH}$-aluminum relationship had to be published later (Dickson 1975; reproduced here as Fig. 2).

Thanks to the Ambio report in 1974, the doors to different workshop opened up for us. In a conference in Norway in 1976, the Swedish Environmental Protection Agency presented the plan to lime lakes with a budget of SEK 50 million (in the monetary value of 2021, approx. $€$ 25 million) in the following year and initiated a research program on acidification. At the tenth anniversary of the first UN Environment Conference in 1982, the Swedish Environmental Protection Agency was well prepared and the acidification information was presented in many languages and with summaries in both Russian and Japanese.

In 2021, the acid deposition has decreased by more than $90 \%$ compared to the beginning of the 1970s and the $\mathrm{pH}$ in 


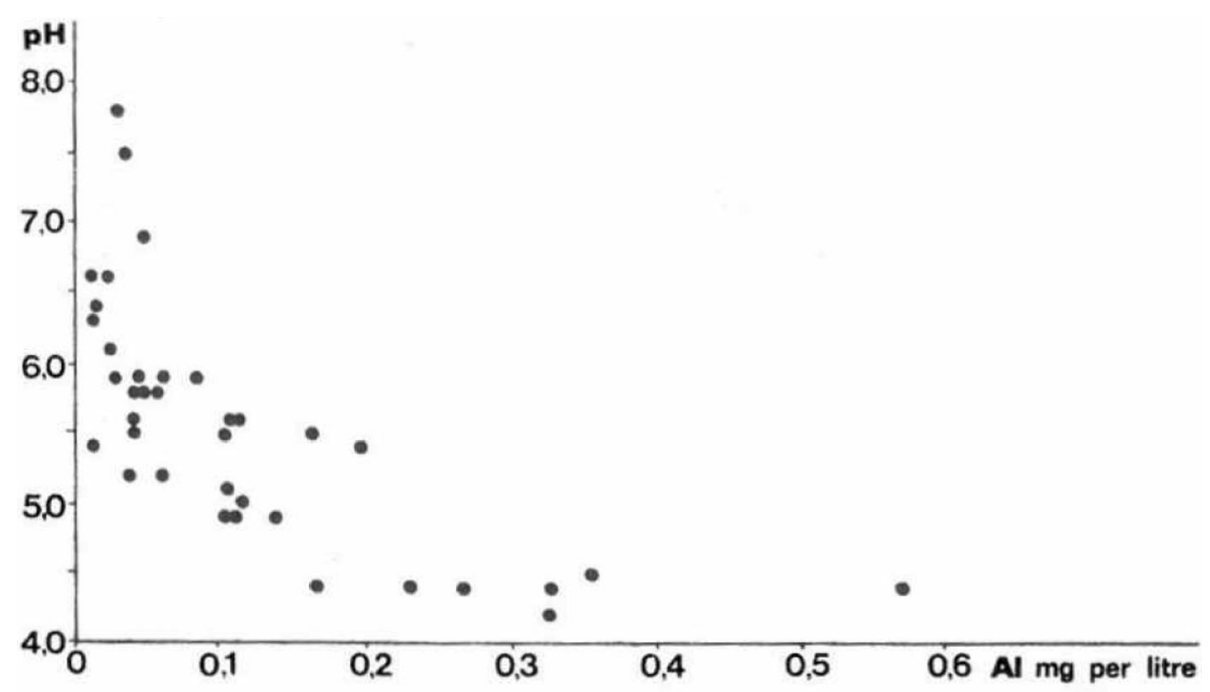

Fig. 7. Aluminium content in clear-water lakes. The solubility rises at low $\mathrm{pH}$.

Fig. 2 The missing figure on the link between $\mathrm{pH}$ and aluminum in lake water that did not make it into the original article. High and toxic levels of aluminum are found in lake water at $\mathrm{pH}<6$. Considering that soils contain large stocks of soluble aluminum that may be transported to the lakes, this is of high concern (Dickson 1975)

the precipitation has risen from $\mathrm{pH} 4.2$ and is now approaching $\mathrm{pH}$ 5. Even in the acidification-sensitive waters conditions have improved. Many thousands of lakes and watercourses have been limed at a cost of SEK 6000 million (approx. $€ 600$ million) since the start in 1970. The hydrology professor Erik Eriksson coined already in 1970 the expression "the forest soil has a long memory" and the acidification effects are still visible. When forest soils are fertilized with nitrogen today, some lime is added to counteract the ion exchange in the groundwater and thus the acid shocks in the run-off water.

Following the early days of discovery and research on the acidification of inland waters, we pursued long careers in protection of lakes and streams. William Dickson worked for 33 years at the Swedish Environmental Protection Agency, heavily engaged in liming programs and hence sometimes called "Liming Jesus." Brodde Almer became Fisheries Consultant in the county of Halland in 1978, an honorary member of national angler association, and received the Hallman Prize from Princess Christina's hand "For his valuable contribution of promoting angling." Other contributors include Einar Hörnström (phytoplankton) who received his doctorate in limnology in 1999, Christina Ekström (zooplankton) who was a Hydrobiologist, and Urve Miller (diatoms) who came as a refugee from Estonia to Sweden in 1944 and worked as a Professor at Geological Survey of Sweden.
The effects of acidification and liming on soil and water have so far engaged two generations of researchers and officials. Most importantly, their work has contributed to cleaner air and water.

\section{REFERENCES}

Almer, B. 1972. The effect of acidification on the lakes of the west coast of Sweden. Information 12. Drottningholm: Institute of Freshwater Research.

Almer, B., W. Dickson, C. Ekström, and E. Hörnström. 1974. Effects of acidification on Swedish lakes. Ambio 3: 30-36.

Dickson, W. 1975. The acidification of Swedish lakes. Report No. 54. Drottningholm: Institute of Freshwater Research.

Erichsen Jones, J.R. 1939. The relation between the electrolytic solution pressures of the metals and their toxicity to the stickleback (Gasterosteus aculeatus L.). Journal of Experimental Biology 16: 425-437.

Publisher's Note Springer Nature remains neutral with regard to jurisdictional claims in published maps and institutional affiliations.

Brodde Almer ( $\square)$

Address: Näsum, Sweden.

e-mail: brodde.almer@outlook.com

William Dickson

Address: Telia Company, Stockholm, Sweden.

e-mail: williamdickson@telia.com 